\title{
PENGARUH SISTEM ORGANISASI TERHADAP MOTIVASI KERJA GURU PADA SEKOLAH MENENGAH KEJURUAN NEGERI DI PROVINSI JAMBI
}

\author{
Istikomah \\ Institut Agama Islam Yasni Bungo Jambi \\ Email: istidani88@gmail.com \\ Masriani \\ STAI Auliaurrasyidin Tembilahan Riau \\ Email : riani.muhammadsyah@gmail.com \\ Muhammad Anggung Manumanoso Prasetyo \\ IAIN Lhokseumawe \\ Email : anggung@iainlhokseumawe.co.id
}

\begin{abstract}
Every organization is basically a kind of control system. An irregular organizational system will have a negative impact and lack of control over the performance of the members of the organization. The organizational system also plays a significant role in creating a conducive atmosphere in the school environment. An effective and structured organizational system will provide boundaries and positive direction in the organization. This research is a quantitative research with survey method. From the results of this study it was found that the organizational system significantly influenced the work motivation of teachers in state vocational high schools Jambi Province. Based on the calculation results obtained by the analysis of the value $\mathbf{t}_{\text {hitung }}$ $(9,0)>\mathbf{t}_{\text {tabel }}\left(\mathbf{1 , 9 6 9 )}\right.$, until $\mathrm{H}_{0}$ is rejected and $\mathrm{H}_{1}$ is accepted. This means that the organizational system that is run and maintained within a school organization will be able to provide a significant influence on teacher work motivation. The research implications of these findings explain that the better the organizational system built in this school the better the effect will be on increasing teacher work motivation.
\end{abstract}

Keywords: organizational system, motivation for teacher work.

\begin{abstract}
Abstrak
Setiap organisasi pada dasarnya merupakan sejenis sistem control. Sistem organisasi yang tidak teratur akan memberikan dampak yang negatif dan kurang terkontrolnya kinerja para anggota organisasi. Sistem organisasi juga berperan signifikan dalam menciptakan suasana yang kondusif di lingkungan sekolah. Sistem organisasi yang efektif dan terstruktur akan memberikan batasan dan arahan yang positif dalam organisasi tersebut. Penelitian ini merupakan penelitian kuantitatif dengan metode survey. Dari hasil penelitian ini ditemukan bahwa sistem organisasi berpengaruh
\end{abstract}

Nur El-Islam, Volume 7, Nomor 1, April 2020 
signifikan terhadap motivasi kerja guru pada Sekolah Menengah Kejuruan Negeri di Provinsi Jambi. Berdasarkan hasil perhitungan analisis diperoleh nilai $\mathbf{t}_{\text {hitung }}\left(\mathbf{9 , 0 )}>\mathbf{t}_{\text {tabel }}\right.$ (1,969), sehingga $\mathrm{H}_{0}$ ditolak dan $\mathrm{H}_{1}$ diterima. Ini berarti bahwa sistem organisasi yang dijalankan dan dijaga di dalam suatu organisasi lembaga sekolah akan mampu memberikan pengaruh yang signifikan terhadap motivasi kerja guru. Implikasi penelitian dari temuan ini menjelaskan bahwa semakin baik sistem organisasi yang dibangun di sekolah ini akan semakin baik pengaruhnya terhadap peningkatan motivasi kerja guru.

Kata Kunci: Sistem Organisasi, Motivasi Kerja Guru.

\section{A. Pendahuluan}

Pendidikan sangat penting dan menduduki posisi sentral dalam pembangunan karena berorientasi pada peningkatan kualitas sumber daya manusia. ${ }^{1}$ Pendidikan merupakan suatu proses transformasi nilai-nilai budaya sebagai kegiatan pewarisan budaya dari satu generasi ke generasi yang lain. Nilai-nilai kebudayaan tersebut mengalami proses transformasi dari generasi terdahulu sampai pada generasi sekarang ke depan. ${ }^{2}$

Pendidikan diharapkan dapat menumbuhkan kemampuan untuk menghadapi tuntutan perubahan pada kenyataan masa kini dan masa depan, baik perubahan dari dalam maupun perubahan dari luar. ${ }^{3}$ Salah satu pertimbangan ditetapkannya UU RI No. 20 Tahun 2003 tentang Sistem Pendidikan Nasional bahwa "Sistem pendidikan nasional harus mampu menjamin pemerataan kesempatan pendidikan, peningkatan mutu serta relevansi dan efisiensi manajemen pendidikan untuk menghadapi tantangan sesuai dengan tuntutan perubahan kehidupan

${ }^{1}$ Linda Hancock and Sonia Nuttman, “Engaging Higher Education Institutions in the Challenge of Sustainability: Sustainable Transport as a Catalyst for Action,” Journal of Cleaner Production, 2014, https://doi.org/10.1016/j.jclepro.2013.07.062.

${ }^{2}$ Sukatin, "Budaya Organisasi STAI YASNI Kabupaten Muaro Bungo Provinsi Jambi,” IDARAH | Jurnal Pendidikan Dan Kependidikan 2, no. 2 (2018): 55-73, https://ejurnal.iainlhokseumawe.ac.id/index.php/idarah.

${ }^{3}$ Karen O’Brien et al., "You Say You Want a Revolution? Transforming Education and Capacity Building in Response to Global Change," Environmental Science and Policy 28 (2013): 48-59, https://doi.org/10.1016/j.envsci.2012.11.011. 
lokal, nasional dan global sehingga perlu dilakukan pembaharuan pendidikan secara terencana, terarah dan berkesinambungan". 4

Upaya revitalisasi pengelolaan pendidikan ditunjukkan oleh usaha pemerintah dengan merekonstruksi sistem pendidikan yang ada mulai jenjang pendidikan dasar hingga perguruan tinggi. ${ }^{5}$ Pendidikan atau sekolah yang berkualitas disebut juga sekolah yang berprestasi, sekolah yang baik, sekolah yang efektif, dan sekolah yang unggul. ${ }^{6}$ Seluruh anggota sekolah terutama kepala sekolah dan guru masih harus terus meningkatkan kesadaran bahwa sekolah sebagai suatu sistem sosial merupakan organisasi yang dinamis sebagai tempat berlangsungnya proses pembudayaan dan pemberdayaan peserta didik yang berlangsung sepanjang hayat.

Penyelenggaraan pendidikan di sekolah merupakan suatu lembaga organisasi yang melibatkan banyak komponen, termasuk diantaranya adalah kepala sekolah, guru-guru dan staf tata usaha yang merupakan sumber daya manusia di sekolah. Dalam sebuah organisasi diperlukan suatu kerja yang solid dan dapat berkomunikasi antara sesama pemimpin dan bawahan. ${ }^{7}$

Sekolah merupakan sebuah organisasi yang merupakan sistem sosial. Sistem sosial terdiri dari beberapa komponen struktur, individu, budaya, dan politik. Menurut Mizberg, struktur organisasi adalah kaidah bagaimana anggota-anggota organisasi diberikan tugastugas tertentu dan melakukan koordinasi antar mereka, dan mereka

${ }^{4}$ Abd. Halim Soebahar, Kebijakan Pendidikan Islam Dari Ordonansi Guru Sampai UU Sisdiknas (Depok: Raja Grafindo Persada, 2012). h. 136.

${ }^{5}$ Bashori, Muhammad Anggung Manumanoso Prasetyo, and Edi Susanto, "Change Management Transformation in Islamic Education of Indonesia," Social Work and Educationducation 7, no. 1 (2020): 72-86, https://doi.org/10.25128/25206230.20.1.7.UD.

${ }^{6}$ Istikomah, “Efektivitas Kepemimpinan Kepala Sekolah Pada SMK Negeri 4 Di Kota Jambi," IDARAH | Jurnal Pendidikan Dan Kependidikan 3, no. 2 (2019): 39-55, https://ejurnal.iainlhokseumawe.ac.id/index.php/idarah.

7 Michael Saffa and Mohamed Jabbie, "Developing Transformational Competencies for Sustainable Development," in Quality Education, ed. Walter Leal Filho et al. (Cham: Springer International Publishing, 2020), 149-58, https://doi.org/10.1007/978-3-319-95870-5_116. 
secara individu mempunyai pandangan yang berbeda mengenai tugas mereka dalam organisasi. ${ }^{8}$

Kompleksitas organisasi sebagai sebuah kesatuan terdiri dari sub komponen yang saling mempengaruhi guna mencapai tujuan yang ditentukan. ${ }^{9}$ Tindakan bagian tertentu, akan mempengaruhi bagian lain, dan para pemimpin tidak dapat mengahadapi bagian-bagian individual secara terpisah. Organisasi sebagai sebuah sistem sosioteknikal terbuka yang terdiri dari sejumlah subsistem. Salah satu subsistem yang terpenting adalah tujuan-tujuan dan nilai-nilai keorganisasian. Organisasi yang bersangkutan menarik sebagian besar dari nilai-nilainya dari lingkungan sosiokultural yang lebih luas. ${ }^{10}$

Terdapat kesepakatan yang luas di antara para teoritikus organisasi bahwa persepektif sistem menawarkan pandangan penting mengenai cara kerja sebuah organisasi. Arti sistem adalah kumpulan dari bagian-bagian yang saling berhubungan dan saling bergantung yang diatur sedemikian rupa sehingga menghasilkan suatu kesatuan. ${ }^{11}$ Sedangkan organisasi adalah kesatuan (entity) sosial yang dikoordinasikan secara sadar, dengan sebuah batasan yang relatif dapat diidentifikasi yang bekerja atas dasar yang relatif terus menerus untuk mencapai suatu tujuan bersama atau sekelompok tujuan. ${ }^{12}$

Sistem organisasi yang tidak teratur akan memberikan dampak yang negatif dan kurang terkontrolnya kinerja para anggota organisasi. Sistem organisasi juga berperan signifikan dalam menciptakan suasana yang kondusif di lingkungan sekolah. Sistem

${ }^{8}$ Supardi, Sekolah Efektif, Konsep Dasar Dan Praktiknya, 2nd ed. (Jakarta: Raja Grafindo Persada, 2015). hal. 1.

9 Mitsuru Kodama, "Business Innovation Through Holistic Leadership-Developing Organizational Adaptability," Systems Research and Behavioral Science 36, no. 4 (2019): 365-94.

${ }^{10}$ Colin P. Silverthorne, Organizational Psychology In Cross-Cultural Perspective (New York: New York University Press, 2005). h. 275.

${ }^{11}$ Stephen P. Robbins and T. M. Judge, Organizational Behavior. (12th Ed.) (New Jersey: Pearson Education, 2010). p. 11.

${ }^{12}$ Stephen P. Robbins, Teori Organisasi, Struktur, Desain, \& Aplikasi, Edisi Ke-3, ed. Jusuf Udaya, 3rd ed. (Jakarta: Penerbit Arcan, 2014). h. 4. 
organisasi yang efektif dan terstruktur akan memberikan batasan dan arahan yang positif dalam organisasi tersebut. ${ }^{13}$

Salah satu tantangan yang dihadapi bagi seorang kepala sekolah adalah bagaimana ia dapat megarahkan dan menggerakkan para bawahannya agar mau bekerja sesuai dengan kemampuannya untuk kepentingan sekolah atau organisasi. Salah satu yang perlu dilakukan adalah memotivasi bawahan untuk dapat melaksanakan tugas dan tanggung jawabnya sebagai seorang pegawai yang baik. Kepala sekolah harus memberikan motivasi kepada bawahannya.

Motivasi merupakan dorongan terhadap serangkaian proses perilaku manusia pada pencapaian tujuan. Menurut Siagian motivasi merupakan daya dorong bagi seseorang untuk memberikan kontribusi yang sebesar mungkin demi keberhasilan organisasi mencapai tujuannya. Dengan pengertian, bahwa tercapainya tujuan organisasi berarti tercapai pula tujuan pribadi para anggota yang bersangkutan. ${ }^{14}$

Motivasi merupakan dorongan yang menyebabkan orang berperilaku, baik dorongan dari dalam dirinya (intrinsic motivation) maupun dorongan yang berasal dari luar dirinya (extrinsic motivation). Faktor dari dalam adalah nilai-nilai hidup yang dihayati dengan sepenuh hati, misalnya hidup untuk bekerja, bekerja adalah dalam rangka ibadah. Faktor dari luar diri misalnya harapan akan karir, gaji, bonus atau penghargaan masyarakat. ${ }^{15}$

Motivasi kerja terbentuk dari sikap (attitude) individu dalam menghadapi situasi kerja (situation) di organisasi. Motivasi merupakan kondisi atau energi yang menggerakkan diri individu yang terarah atau tertuju untuk mencapai tujuan organisasi. Sikap mental pro dan

${ }^{13}$ Mukhtar et. al., Pesantren Efektif, Moderl Integratif Kepemimpinan - Komunikasi Konflik Organisasi (Yogyakarta: Deepublish, 2020). h. 25.

${ }^{14}$ Sondang P. Siagian, Kiat Meningkatkan Produktivitas Kerja (Jakarta: Rineka Cipta, 2009). H. 102.

${ }^{15}$ Hanif Ismail and Darsono Prawironegoro, Sistem Pengendalian Manajemen, Konsep Dan Aplikasinya (Jakarta: Mitra Wacana Media, 2009). h. 41. 
positif terhadap situasi kerja tim itulah yang memperkuat motivasi kerjanya untuk mencapai kinerja maksimal. ${ }^{16}$

Motivasi kerja mempunyai dampak penting pada semangat kinerja anggota lembaga sekolah. Diperlukan semangat yang tetap terjaga untuk mencapai suatu tujuan bersama. Faktor motivasi kerja merupakan komponen penting yang perlu dikembangkan dan dikelola dengan baik untuk mencapai tujuan organisasi.

Artikel ini merupakan hasil penelitian menggunakan jenis pendekatan kuantitatif. Sedangkan metode yang digunakan adalah metode deskriptif survei. Cresswell menjelaskan bahwa metode penelitian survei dimana peneliti melakukan survei terhadap sampel atau seluruh populasi orang untuk menggambarkan sikap, perilaku, pendapat, atau karakteristik populasi dengan mengambil contoh data dari satu populasi menggunakan kuesioner sebagai alat pengumpul data pokok. ${ }^{17}$

Penelitian ini bertujuan untuk menganalisis besarnya pengaruh sistem organisasi terhadap motivasi kerja guru pada sekolah menengah kejuruan negeri di provinsi jambi. Sehingga dengan mengetahui dan memahami hasil penelitian ini berarti bahwa sistem organisasi yang dijalankan dan dijaga dalam suatu organisasi lembaga sekolah akan mampu memberikan pengaruh yang signifikan terhadap motivasi kerja guru.

\section{B. Pembahasan}

\section{Pengertian Sistem Organisasi}

Robert D Macredie et. al, ${ }^{18}$ Wibowo ${ }^{19}$ berpendapat bahwa dinamika sistem memandang organisasi sebagai sebuah struktur yang

${ }^{16}$ Anwar Prabu Mangkunegara, Perencanaan Dan Pengembangan Sumber Daya Manusia (Bandung: Refika Aditama, 2010). h. 164.

${ }^{17}$ John W. Cresswell, Educational Research, Planning, Conducting, and Evaluating Quantitative and Qualitative Research (United States of America: Pearson Merrill Prentice Hall, 2012). h. 376.

${ }^{18}$ Robert D Macredie, Carl Sandom, and Ray J Paul, “Modelling for Change : An Information Systems Perspective on Change Management Models" (Brunel University, Uxbridge, Middlesex, 1991). 
saling terhubung, terdiri dari beberapa komponen penggerak yang saling mempengaruhi. Dengan sejumlah yang harus dicapai melalui serangkaian proses pengambilan keputusan yang diidealisasi. Implementasi dari keputusan-keputusan penyusunan kebijakan, yang menerjemahkan sasaran-sasaran dari wilayah potensial pun menjadi hal yang aktual. Secara keseluruhan ini berlangsung didalam sebuah sistem umpan balik yang berinteraksi yang bersifat kompleks dan berkelanjutan. ${ }^{20}$

Sistem berasal dari bahasa Yunani, system. Sistem menurut Shore and Voich adalah suatu keseluruhan yang terdiri dari sejumlah bagian-bagian. Sistem menurut Banghart ialah sekelompok elemenelemen yang saling berkaitan yang secara bersama-sama diarahkan untuk mencapai tujuan yang ditentukan. Menurut Richard A. Johnson, Fremont E. Kasr, James E. Rosenzweig sistem adalah keseluruhan yang terorganisir atau kompleks; kumpulan atau kombinasi benda atau bagian yang membentuk kesatuan yang kompleks. ${ }^{21}$

Koontz dan O'donnel mendefinisikan sistem sebagai keseluruhan bukan hanya bagian-bagian karena sistem yang bersangkutan perlu dipandang sebagai suatu totalitas. Sistem dapat dipandang sebagai suatu hal yang tertutup atau terbuka. Sistem tertutup ialah sistem yang tidak dipengaruhi dan memengaruhi lingkungannya, sedangkan sistem terbuka ialah sistem yang dipengaruhi dan memengaruhi lingkungannya. ${ }^{22}$

Dalam hal adanya sistem terbuka (open system), maka komponen-komponen sistem berinteraksi pula secara erat dengan lingkungan yang mengelilingi sistem yang bersangkutan. Keberhasilan sistem tersebut tergantung pada eratnya kerjasama secara harmonis

${ }^{19}$ Wibowo, Manajemen Kinerja Edisi Ke 5 (Jakarta: Raja Grafindo Persada, 2017). h. 78. 2013).

${ }^{20}$ Nanang Fattah, Analisis Kebijakan Pendidikan, 2nd ed. (Bandung: Rosda Karya,

${ }^{21}$ Kahri Nisjar and Winardi, Teori Sistem Dan Pendekatan Sistem Dalam Bidang Manajemen (Bandung: Mandar Maju, 1997). h. 44.

${ }^{22}$ Husaini Usman, Manajemen, Teori, Praktik, Dan Riset Pendidikan Edisi 4, 4th ed. (Jakarta: Bumi Aksara, 2013). h. 52. 
dan terpadu dengan lingkungannya, hingga pada akhirnya dicapai kondisi "simbiosis-mutualis". Dalam setiap sistem, akan dijumpai adanya unsur-unsur berikut ${ }^{23}$ masukan (input); proses (process); keluaran (output); umpan balik (feedback); dan umpan balik kedepan (feedforward).

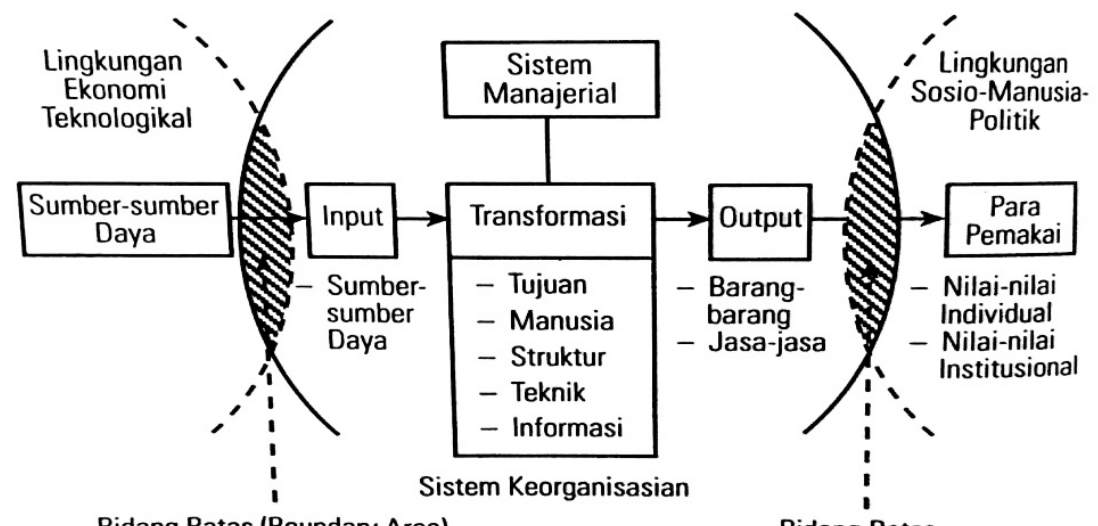

Bidang Batas (Boundary Area)

Bidang Batas

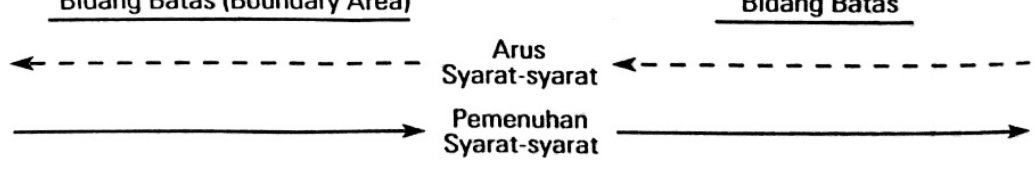

Gambar 1. Organisasi sebagai sebuah sistem input-output terbuka, menurut William Shrode.

Konsep organisasi sebagai sistem yang dihubungkan dengan sistem yang lebih luas memperkenalkan pentingnya arti umpan balik (feedback), karena organisasi itu tergantung pada lingkungannya. Tidak hanya input saja, tetapi juga penerimaan outputnya. ${ }^{24}$ Arus masukan dan keluaran merupakan titik tolak dalam uraian tentang organisasi. Dengan kata lain, organisasi mengambil sumber (input) dari sistem yang lebih luas (environment) memproses sumber ini dan

${ }^{23}$ J. Winardi, Teori Organisasi Dan Pengorganisasian, Cet ke-8 (Jakarta: Raja Grafindo Persada, 2014). h. 45.

${ }^{24}$ Ismail Nawawi Uha, Budaya Organisasi, Kepemimpinan Dan Kinerja (Jakarta: Kencana Prenada Media Grup, 2015). h. 195. 
mengembalikannya dalam bentuk yang diubah (output). Secara sederhana organisasi mengambil sumber daya dengan mengubahnya dalam bentuk lain secara efektif dan efisien. ${ }^{25}$

Desain sistem organisasi memiliki beberapa ciri sebagai berikut (a) adanya sasaran yang menyeluruh dan bermakna; (b) adanya kesatuan desisional manajerial terspesialisasi tertentu (subsistemsubsistem) dalam pencapaian sasaran-sasaran; (c) memerlukan suatu seri input-proses yang memberikan nilai tambah kepada input--output; (d) terdapat hubungan environmental (lingkungan) para pelangganpublik umum-pemerintah; (e) diperlukan tindakan evaluasi dan pengawasan. ${ }^{26}$

Bagian dalam sistem organisasi yang merupakan suatu ikatan utuh dan tidak dapat dipisahkan antara satu dengan lainnya, dapat dilihat pada gambar berikut:

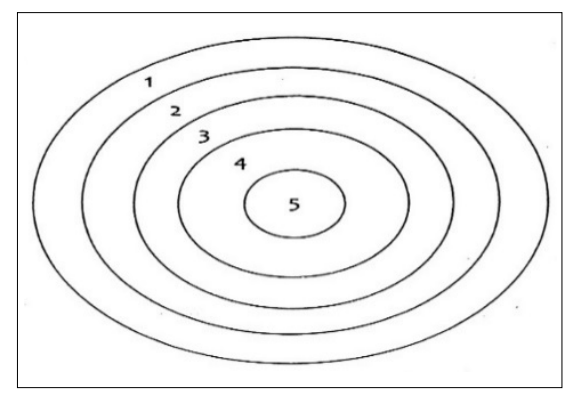

Gambar 2. Sistem Organisasi

Sebagai keterangan dari gambar di atas adalah: (1) simbol persegi empat adalah administrasi, memberikan konseptual yang berlaku secara universal yang mengarah pada proses kerjasama yang dilandasi pemikiran rasional; (2) simbol lingkaran pertama adalah

${ }^{25}$ Marianne E. Krasny and Wolff Michael Roth, “Environmental Education for Social-Ecological System Resilience: A Perspective from Activity Theory,” Environmental Education Research 16, no. 5-6 (2010): 545-58, https://doi.org/10.1080/13504622.2010.505431.

${ }^{26}$ George P. Schell and Raymond McLeod, Management Information System, 9th Edition (New Jersey: Prentice Hall, 2014). p. 356. 
organisasi. Apabila administrasi memberikan pemaknaan keteraturan dalam kerjasama manusia maka organisasi berfungsi sebagai wadah berserikat manusia untuk melakukan kerjasama; (3) simbol lingkaran kedua ialah manajemen. Memikirkan pelaksanaan suatu kegiatan yang telah ditentukan sebelumnya, dengan membagi habis kegiatan kedalam unit-unit organisasi secara profesional; (4) simbol lingkaran ketiga adalah kepemimpinan. Berfungsi untuk mengarahkan manusia yang melakukan kerjasama, sehingga terlaksana kepercayaan (trust) antara satu dan yang lainnya dan (5) simbol lingkaran keempat adalah hubungan manusia. Aktivitas organisasi akan mengalami hambatan atau kelancaran sangat tergantung kepada hubungan baik atau tidaknya manusia. Afektivitas dan efisiensi pelaksanaan daripada aktivitas atau kegiatan administrasi juga ditentukan oleh perilaku dari seluruh manusia dalam organisasi. ${ }^{27}$

Sekolah ialah sistem sosial terbuka dengan lima elemen penting, yaitu perorangan, struktural, kebudayaan, politik, dan pendidikan. Kebiasaan organisasi ialah fungsi dari interaksi dari elemen yang ada dalam hal untuk mengajar dan mempelajari, sementara itu proses mengajar dan mempelajari adalah inti secara teknis dari sistem sosial sekolah. Ini merupakan proses kompleks yang dapat digunakan dari tiga perspektif, yaitu kebiasaan, kesadaran dan konstruksi. Lingkungan juga adalah sebuah aspek kritis dari kehidupan organisasi, ini tidak hanya menyediakan sumber untuk sistem, tetapi juga terdapat paksaan dan kesempatan, serta kita juga membuat posisi sebagai dalil, dimana hal lain menjadi sama, dan juga diantara elemen yang ada tersebut menjadi faktor yang efektif dalam sistem yang ada. Model sistem terbuka dari sekolah menyediakan dasar konsep untuk analisis organisasi dan memecahkan masalah yang ada. ${ }^{28}$

Berbagai macam organisasi saat ini telah dikelola secara sistem, artinya bahwa sumber daya manusia yang ada di dalam organisasi, baik organisasi berukuran kecil maupun berukuran besar, telah

${ }^{27}$ Uha, Budaya Organisasi, Kepemimpinan Dan Kinerja. h. 186.

${ }^{28}$ Veithzal Rivai and Sylviana Murni, Education Management. Analisis Teori Dan Praktek (Jakarta: Raja Grafindo Persada, 2009). h. 195. 
melakukan kegiatan organisasi melalui fungsinya masing-masing tanpa harus menunggu intruksi atasan tentang apa yang harus dikerjakannya.

Gordon B. Davis ${ }^{29}$ dan Danang Sunyoto menjelaskan bahwa sistem organisasi terdiri dari bagian-bagian yang bersama-sama beroperasi untuk mencapai beberapa tujuan, dengan kata lain bahwa suatu sistem bukanlah merupakan suatu perangkat unsur-unsur yang dapat diidentifikasikan sebagai kebersamaan yang menyatu disebabkan tujuan atau sasaran yang sama. ${ }^{30}$

Sekolah dipahami sebagai suatu organisasi, tetapi berbeda dengan organisasi lain terutama organisasi yang berorientasi nirlaba, dimana sekolah merupakan organisasi sosial dan organisasi moral. Sebagai suatu organisasi, sekolah memerlukan seorang pemimpin yang mampu menciptakan sebuah visi masa depan sekolahnya dan mengilhami warga sekolah dan semua komponen individu yang terkait dengan sekolah untuk mau dan mampu berbuat untuk kepentingan pencapaian tujuan sekolah. ${ }^{31}$

Berdasarkan paparan teori yang telah diuraikan oleh para ahli, sebagai sintesa dari variabel sistem organisasi dalam penelitian ini adalah bagian-bagian organisasi yang berkaitan dan saling mempengaruhi yang secara bersama-sama diarahkan untuk mencapai tujuan organisasi.

\section{Pengertian Morivasi Kerja}

Motif adalah dorongan (driving force) yang menggerakkan manusia untuk bertingkah laku dan di dalam perbuatannya itu mempunyai tujuan tertentu. ${ }^{32}$ Bernard Berelson dan Gary A. Steiner

${ }^{29}$ Keith Davis and John W. Newstrom, Perilaku Dalam Organisasi, Jilid 1, Edisi Ke7, 3rd ed. (Jakarta: Erlangga, 1993).

30 Danang Sunyoto, Sistem Informasi Manajemen (Perspektif Oragnisasi) (Yogyakarta: Buku Seru, 2014). h. 33.

${ }^{31}$ Cepi Triatna, Perilaku Organisasi Dalam Pendidikan Dalam Pendidikan (Bandung: Remaja Rosda Karya, 2016). h. 26.

${ }^{32}$ Roland Bénabou and Jean Tirole, "Intrinsic and Extrinsic Motivation," The Review of Economic Studies 70, no. 3 (July 1, 2003): 489-520, https://doi.org/10.1111/1467-937X.00253. 
motivasi dapat diartikan sebagai keadaan kejiwaan dan sikap mental manusia yang memberikan energi, mendorong kegiatan, dan mengarahkan atau menyalurkan perilaku ke arah mencapai kebutuhan yang memberi kepuasan atau mengurangi ketidakseimbangan. ${ }^{33}$

Menurut George. R. Terry mengungkapkan bahwa motivasi dapat diartikan sebagai mengusahakan supaya seseorang dapat menyelesaikan pekerjaan dengan semangat karena ia ingin melaksanakannya. ${ }^{34}$ Dan dari perspektif manajemen motivasi adalah usaha sadar untuk mempengaruhi perilaku seseorang agar supaya mengarah tercapainya tujuan organisasi. ${ }^{35}$

Motivasi diartikan sebagai kekuatan, dorongan, kebutuhan, semangat, tekanan, atau mekanisme psikologi yang mendorong seseorang atau sekelompok orang untuk mencapai prestasi tertentu sesuai dengan apa yang dikehendakinya. Dalam arti kognitif, motivasi diasumsikan sebagai aktivitas individu untuk menentukan kerangka dasar tujuan dan penentuan perilaku untuk mencapai tujuan itu. Dalam arti afektif, motivasi bermakna sikap dan nilai dasar yang dianut oleh seseorang atau sekelompok orang untuk bertindak atau tidak bertindak. Istilah motivasi paling tidak memuat tiga unsur esensial. Pertama, faktor pendorong atau pembangkit motif, baik internal maupun eksternal. Kedua, tujuan yang ingin dicapai. Ketiga, strategi yang diperlukan oleh individu atau kelompok untuk mencapai tujuan tersebut. ${ }^{36}$

Sedangkan Colquitt, Lepine, dan Wesson memberikan definisi motivasi sebagai sekumpulan kekuatan energik yang dimulai baik dari dalam maupun diluar pekerja, dimulai dari usaha yang berkaitan dengan pekerjaan, dan mempertimbangkan arah, intensitas dan

${ }^{33}$ Meir Steiner et al., "Motivated Behavior and The Estrous Cycle in Rats," Psychoneuroendocrinology 6, no. 1 (1981): 81-90.

${ }^{34}$ George R. Terry, Prinsip-Prinsip Manajemen (Jakarta: Bumi Aksara, 2009). h. 130.

35 Tubagus Achmad Darodjat, Konsep-Konsep Dasar Manajemen Personalia Masa Kini (Bandung: Refika Aditama, 2015). h. 187.

${ }^{36}$ Sudarwan Danim, Motivasi Kepemimpinan \& Efektivitas Kelompok, 2nd ed. (Jakarta: Rineka Cipta, 2012). h.2. 
ketekunannya. Motivasi adalah pertimbangan kritis karena kinerja yang efektif sering memerlukan baik kemampuan dan motivasi tingkat tinggi. ${ }^{37}$

Usman mengemukakan teknik motivasi dapat dilakukan dengan cara, (1) berpikir positif, yakni berpikir bahwa apa yang dikerjakan akan mencapai kesuksesan; (2) menciptakan perubahan yang kuat, perubahan dari keadaan yang buruk ke arah yang lebih baik; (3) membangun harga diri, harga diri merupakan suatu prinsip hidup yang diperjuangkan dan dipertahankan; (4) memantapkan pelaksanaan, konsisten dengan prosedur dan proses untuk mencapai kesuksesan; (5) membangkitkan orang lemah menjadi kuat; (6) membasmi sikap suka menunda-nunda. ${ }^{38}$

Menurut Hoy dan Miskel dalam buku Educational Administration yang dikutip oleh Ngalim mengemukakan bahwa motivasi dapat didefinisikan sebagai kekuatan-kekuatan yang kompleks, dorongandorongan, kebutuhan-kebutuhan, pernyataan-pernyataan ketegangan, atau mekanisme-mekanisme lainnya yang memulai dan menjaga kegiatan-kegiatan yang diinginkan ke arah pencapaian tujuan-tujuan personal. ${ }^{39}$

Tiga karakteristik pokok motivasi, yaitu: (1) usaha: menunjuk kepada kekuatan perilaku kerja seseorang atau jumlah yang ditunjukkan oleh seseorang dalam pekerjaannya; (2) kemauan yang kuat: kemauan keras yang ditunjukkan oleh ketika fokus pada pekerjaannya; (3) arah atau tujuan: arah yang dituju oleh usaha dan kemauan keras yang dimiliki oleh seseorang. Dengan melihat ketiga karakteristik pokok motivasi di atas maka motivasi dapat didefinisikan sebagai keadaan di mana usaha dan kemauan keras seseorang diarahkan kepada pencapaian hasil-hasil atau tujuan tertentu. Hasil-

${ }^{37}$ Jason A. Colquit, Jeffery A. LePine, and Michael J. Wesson, Organizational Behavior, Improving Performance and Commitment It the Workplace, Internatio (New York: McGraw-Hill lnternational, Inc., 2011). h. 179.

${ }^{38}$ Usman, Manajemen, Teori, Praktik, Dan Riset Pendidikan Edisi 4. h. 301.

${ }^{39}$ Wayne K. Hoy and Cecil G. Miskel, Educational Administration Theory, Research, and Practice 6th Ed., International Edition (Singapore: McGraw-Hill Co, 2008). h. 72. 
hasil yang dimaksud berupa produktivitas, kehadiran atau perilaku kerja kreatif lainnya. ${ }^{40}$

Motivasi merupakan dorongan yang menyebabkan orang berperilaku, baik dorongan dari dalam dirinya (intrinsic motivation) maupun dorongan yang berasal dari luar dirinya (extrinsic motivation). Faktor dari dalam adalah nilai-nilai hidup yang dihayati dengan sepenuh hati, misalnya hidup untuk bekerja, bekerja adalah dalam rangka ibadah. Faktor dari luar diri misalnya harapan akan karir, gaji, bonus atau penghargaan masyarakat. ${ }^{41}$

Motivasi kerja terbentuk dari sikap (attitude) individu dalam menghadapi situasi kerja (situation) di organisasi. Motivasi merupakan kondisi atau energi yang menggerakkan diri individu yang terarah atau tertuju untuk mencapai tujuan organisasi. Sikap mental pro dan positif terhadap situasi kerja tim itulah yang memperkuat motivasi kerjanya untuk mencapai kinerja maksimal. ${ }^{42}$

Motivasi kerja adalah hasil dari kumpulan kekuatan internal dan eksternal yang menyebabkan pekerja memilih jalan bertindak yang sesuai dan menggunakan perilaku tertentu. Idealnya, perilaku ini akan diarahkan pada pencapaian tujuan organisasi. ${ }^{43}$

Sementara itu, Newstrom mengemukakan bahwa sebagai indikator motivasi adalah:44 (a) engagement; hal yang menunjukkan tingkat antusiasme, inisiatif, dan usaha untuk meneruskan; (b) commitment; suatu tingkatan dimana pekerja mengikat dengan organisasi dan menunjukkan tindakan organizational citizenship; (c) satisfaction; kepuasan merupakan refleksi pemenuhan kontrak psikologis dan memenuhi harapan ditempat kerja; (d) turnover; merupakan kehilangan pekerja yang dihargai.

${ }^{40}$ Sopiah, Perilaku Organisasi (Yogyakarta: Andi Publishing, 2018). h. 170.

${ }^{41}$ Steven L. McShane and Mary Ann Von Glinow, Organizational Behaviour: Emerging Knowledge Global Reality (New York: McGraw-Hill Education, 2018). h. 41.

${ }^{42}$ Mangkunegara, Perencanaan Dan Pengembangan Sumber Daya Manusia. h. 164.

${ }^{43}$ A. Wigfield and J. S. Eccles, Development of Achievement Motivation (San Diego: Academic Press, 2002).

${ }^{44}$ Keith Davis and John W. Newstrom, Organizational Behavior, Seventh Edition, Perilaku Dalam Organisasi, Jilid 1, Edisi Ke-7, Terj. Agus Dharma (Jakarta: Erlangga, 2013). h. 110. 
Ada beberapa teori motivasi yang dikembangkan oleh pakar ilmu perilaku administrasi yang menurut Gibson et al. Secara umum mengacu pada dua kategori, yaitu (1) teori isi/kepuasan (content Theory), yang memusatkan perhatian kepada faktor dalam diri orang yang menguatkan (energize), mengarahkan (direct), mendukung (sustain) dan menghentikan (stop) perilaku petugas dan (2) teori proses (process Theory) menguraikan dan menganalisa bagaimana perilaku itu dikuatkan, diarahkan, didukung dan dihentikan. ${ }^{45}$

Ada dua faktor yang mempengaruhi kondisi pekerjaan seseorang, yaitu faktor pemuas (motivation factor) yang disebut juga dengan satisfier atau instrinsic motivation dan faktor kesehatan (hygienes) yang juga disebut disatisfier atau extrinsic motivation. Teori Herzberg ini melihat ada dua faktor yang mendorong karyawan termotivasi yaitu faktor intrinsik yaitu daya dorong yang timbul dari dalam diri masing-masing orang, dan faktor ekstrinsik yaitu daya dorong yang datang dari luar diri seseorang, terutama dari organisasi tempatnya bekerja. ${ }^{46}$

Tabel 1: Dua Faktor Intrinsik dan Ekstrinsik

\begin{tabular}{|l|l|}
\hline Faktor Motivasi (Intrinsik) & Faktor Kesehatan (Ekstrinsik) \\
\hline 1. Prestasi (achievement) & 1. Supervisi \\
2. Penghargaan (recognition) & 2. Kondisi kerja \\
3. Pekerjaan itu sendiri & 3. Hubungan interpersonal \\
4. Tanggung jawab & 4. Bayaran dan keamanan \\
5. Pertumbuhan dan perkembangan & 5. Kebijakan perusahaan \\
\hline
\end{tabular}

Motivasi kerja adalah prakondisi bagi individu untuk berperilaku di dalam pekerjaan yang dia tekuni. Motivasi yang tinggi cenderung menghasilkan prestasi yang tinggi dan motivasi yang rendah cenderung menghasilkan prestasi yang rendah, demikian juga dalam

${ }^{45}$ James L. Gibson, Organizations; Behavior, Structure, Processes., 14th Editi (Singapore: McGraw-Hill lnternational, Inc., 2011). h. 251.

${ }^{46}$ Wirawan, Kepemimpinan, Teori, Psikologi, Perilaku Organisasi, Aplikasi Dan Penelitian, Contoh Aplikasi Untuk Kepemimpinan Wanita, Organisasi Bisnis, Pendidikan, Dan Militer (Jakarta: Raja Grafindo Persada, 2017). h. 680-681. 
penghargaan. ${ }^{47}$ Stokes dalam Kadarisman mengemukakan motivasi kerja adalah penggerak atau pendorong dalam diri seseorang untuk mau berperilaku dan bekerja dengan giat dan baik sesuai dengan tugas dan kewajiban yang telah diberikan kepadanya. ${ }^{48}$

Sebagai sintesis yang dimaksud motivasi kerja adalah doronga yang membangkitkan kemauan individu dan membentuk sikap aktif dalam bekerja untuk mencapai tujuan organisasi.

\section{Hasil Penelitian}

Data penelitian berupa data hasil angket dari variabel bebas yaitu sistem organisasi terhadap variabel terikat yaitu motivasi kerja guru. Dalam penelitian ini digunakan sampel sebanyak 146 guru yaitu pada bagian ini akan disajikan deskripsi data dari tiap-tiap variabel meliputi: a) perhitungan statistik deskriptif yaitu berupa: skor tertinggi, skor terendah, mean (M), dan standar deviasi (SD); dan b) pengujian hipotesis. pengolahan data menggunakan SPSS Versi 22.00.

Perhitungan statistik deskriptif mean, median dan modus variabel sistem organisasi (X) dengan perhitungan berbantuan program SPSS 22.0 sebagai berikut:

Tabel 2. Statistics Sistem Organisasi X

\begin{tabular}{|ll|l|}
\hline $\mathrm{N}$ & \multicolumn{1}{c|}{ Valid } & 146 \\
\multicolumn{1}{|c|}{ Missing } & 0 \\
Mean & 129.65 \\
Median & 130.68 \\
Mode & 131.64 \\
Std. Deviation & 9,99 \\
Range & 63
\end{tabular}

${ }^{47}$ Mukhtar, Risnita, and Istikomah, “The Influence of Principals' Leadership Style, the Organizational System and Work Motivation on School Effectiveness," International Journal of Scientific and Technology Research 8, no. 11 (2019): 91-104.

${ }^{48}$ Kadarisman, Manajemen Pengembangan Sumber Daya Manusia (Jakarta: Raja Grafindo Persada, 2013). h. 278. 


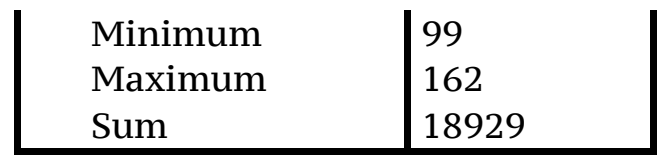

Perhitungan statistik deskriptif mean, median dan modus variabel motivasi kerja guru (Y) dengan perhitungan berbantuan program SPSS 22.00 sebagai berikut:

Tabel 3. Statistics Motivasi Kerja Y

\begin{tabular}{|ll|l|}
\hline N & \multicolumn{1}{c|}{ Valid } & 146 \\
Missing & 0 \\
Mean & 126.97 \\
Median & 123.39 \\
Mode & 124.74 \\
Std. Deviation & 14.55 \\
Range & 82 \\
Minimum & 83 \\
Maximum & 165 \\
Sum & 18537 \\
\hline
\end{tabular}

Hasil perhitungan Hipotesis menyatakan sistem organisasi (X) berpengaruh langsung terhadap motivasi kerja guru (Y). Hipotesis statistik:

$$
\begin{aligned}
& \mathrm{H}_{0}: \mathrm{p}_{41} \geqslant 0 \\
& \mathrm{H}_{1}: \mathrm{p}_{41}<0
\end{aligned}
$$

Kriteria pengujian hipotesis $\mathrm{H}_{0}$ ditolak jika nilai $t_{\text {hitung }}>t_{\text {tabel}}$, dan $\mathrm{H}_{0}$ diterima jika nilai $\mathrm{t}_{\text {hitung }}<\mathrm{t}_{\text {tabel. }}$. Berdasarkan hasil analisis data secara manual diperoleh koefisien jalur $\mathrm{X}_{2}$ terhadap $\mathrm{X}_{3}\left(\rho_{\mathrm{XY}}\right)=0,87$, dengan taraf nyata $\alpha=0,05 \mathrm{dan} \mathrm{dk}=144$ diperoleh nilai $\mathrm{t}_{\text {tabel }}=1,960$. Hasil perhitungan mendapatkan nilai $t_{\text {hitung }}=9,0$.

Perhitungan menggunakan bantuan SPSS ver.22.0 dapat dilihat pada tabel 4 berikut: 
Pengaruh Sistem Organisasi ...

Tabel 4. Hasil Analisis Jalur antara variabel Sistem Organisasi (X) dengan Motivasi Kerja (Y)

Coefficients $^{\mathrm{a}}$

\begin{tabular}{|c|c|c|c|c|c|c|}
\hline \multirow{2}{*}{\multicolumn{2}{|c|}{ Model }} & \multicolumn{2}{|c|}{$\begin{array}{l}\text { Unstandardized } \\
\text { Coefficients }\end{array}$} & \multirow{2}{*}{$\begin{array}{l}\text { Standardized } \\
\text { Coefficients } \\
\text { Beta } \\
\end{array}$} & & \multirow[t]{2}{*}{ Sig. } \\
\hline & & B & Std. Error & & & \\
\hline \multirow[b]{2}{*}{1} & (Constant) & 115.108 & 15.881 & & 7.248 & .000 \\
\hline & $\begin{array}{l}\text { X_Sistem } \\
\text { Organisasi }\end{array}$ & .091 & .122 & .87 & 9 & .455 \\
\hline
\end{tabular}

a. Dependent Variable: Y_Motivasi Kerja

Pada tabel 4 hasil perhitungan menggunakan bantuan program SPSS, menunjukkan nilai koefisen jalur yang sama yaitu $\rho_{X Y}=0,87$.

Hasil hipotesis ditemukan bahwa sistem organisasi $(\mathrm{X})$ memiliki pengaruh yang signifikan terhadap motivasi kerja guru (Y). Hal itu dapat diperhatikan dari hasil analisis data secara manual diperoleh koefisien jalur $\mathrm{X}_{2}$ terhadap $\mathrm{X}_{3}\left(\rho_{\mathrm{XY}}\right)=0,87$, dengan taraf nyata $\alpha=0,05$ dan $\mathrm{dk}=144$ diperoleh nilai $t_{\text {tabel }}=1,960$. Hasil perhitungan mendapatkan nilai $t_{\text {hitung }}=9,0$. Berdasarkan kriteria tersebut ternyata

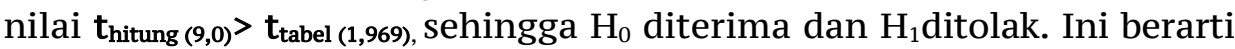
bahwa hipotesis penelitian yang menyatakan sistem organisasi (X) berpengaruh langsung terhadap motivasi kerja (Y) dapat diterima karena teruji kebenarannya.

Menyimak dari hasil olahan data menggunakan bantuan program SPSS diatas, dapat dijelaskan ternyata sistem organisasi yang berlaku dan dijalankan di dalam suatu lembaga organisasi memberikan pengaruh kepada motivasi kerja seseorang. Dengan kata lain berdasarkan hasil penelitian ini terbukti bahwa motivasi kerja guru dapat dipengaruhi oleh sistem organisasi yang ada di lembaga organisasi tersebut. Hasil penelitian sejalan dengan kajian yang 
dilakukan beberapa peneliti seperti Saira et.al., ${ }^{49}$, Gilley et.al, ${ }^{50}$ Siregar ${ }^{51}$ dan Mahendra et.al., ${ }^{52}$.

\section{Penutup}

Berdasarkan analisis pengolahan data dan pembahasan yang telah dipaparkan, maka Sistem organisasi berpengaruh langsung terhadap motivasi kerja pada Sekolah Menengah Kejuruan Negeri di Provinsi Jambi. Berdasarkan hasil perhitungan analisis diperoleh nilai $t_{\text {hitung }(9,0)}>t_{\text {tabel }(1,969) \text {, sehingga }} H_{0}$ ditolak dan $H_{1}$ diterima. Ini berarti bahwa sistem organisasi yang dijalankan dan dijaga di dalam suatu organisasi lembaga sekolah akan mampu memberikan pengaruh yang signifikan terhadap motivasi kerja.

Sudah semestinya kepala sekolah membangun sistem organisasi yang mengarah pada pengelolaan dan layanan di sekolah dengan cara membuat struktur organisasi yang sesuai dengan keahlianya masingmasing, membuat perencanaan strategi yang matang, menjalin komunikasi yang baik dengan guru dan staf, dan selalu koordinasi semua tugas yang diberikan kepada guru dan staf di sekolah.

\section{Daftar Pustaka}

Bashori, Muhammad Anggung Manumanoso Prasetyo, and Edi Susanto. "Change Management Transformation in Islamic Education of Indonesia." Social Work and Educationducation 7, no.

${ }^{49}$ Saira Yousaf et.al., "Impact of Financial and Non Financial Rewards on Employee Motivation," Middle-East Journal of Scientific Research 21, no. 10 (2014).

${ }^{50}$ Ann Gilley, Jerry W Gilley, and Heather S Mcmillan, “Organizational Change: Motivation, Communication, and Leadership Effectiveness," Wiley Inter Science 21, no. 1 (2009): 75-94, https://doi.org/10.1002/piq.

${ }^{51}$ Fauzan Ahmad Siregar, "Membangun Loyalitas Tenaga Pendidik," IDARAH |

Jurnal Pendidikan Dan Kependidikan 1, no. 1 (2017): 117-28, https://ejurnal.iainlhokseumawe.ac.id/index.php/idarah.

${ }^{52}$ Angga Martha Mahendra, Ery Tri Djatmika, and Agus Hermawan, “The Effect of Entrepreneurship Education on Entrepreneurial Intention Mediated by Motivation and Attitude among Management Students, State University of Malang, Indonesia," International Education Studies, 2017, https://doi.org/10.5539/ies.v10n9p61. 
1 (2020): 72-86. https://doi.org/10.25128/2520-6230.20.1.7.UD.

Bénabou, Roland, and Jean Tirole. "Intrinsic and Extrinsic Motivation." The Review of Economic Studies 70, no. 3 (July 1, 2003): 489-520. https://doi.org/10.1111/1467-937X.00253.

Colquit, Jason A., Jeffery A. LePine, and Michael J. Wesson. Organizational Behavior, Improving Performance and Commitment It the Workplace. Internatio. New York: McGraw-Hill lnternational, Inc., 2011.

Cresswell, John W. Educational Research, Planning, Conducting, and Evaluating Quantitative and Qualitative Research. United States of America: Pearson Merrill Prentice Hall, 2012.

Danim, Sudarwan. Motivasi Kepemimpinan \& Efektivitas Kelompok. 2nd ed. Jakarta: Rineka Cipta, 2012.

Darodjat, Tubagus Achmad. Konsep-Konsep Dasar Manajemen Personalia Masa Kini. Bandung: Refika Aditama, 2015.

Davis, Keith, and John W. Newstrom. Organizational Behavior, Seventh Edition, Perilaku Dalam Organisasi, Jilid 1, Edisi Ke-7, Terj. Agus Dharma. Jakarta: Erlangga, 2013.

-_- Perilaku Dalam Organisasi, Jilid 1, Edisi Ke-7. 3rd ed. Jakarta: Erlangga, 1993.

Fattah, Nanang. Analisis Kebijakan Pendidikan. 2nd ed. Bandung: Rosda Karya, 2013.

Gibson, James L. Organizations; Behavior, Structure, Processes. 14th Editi. Singapore: McGraw-Hill International, Inc., 2011.

Gilley, Ann, Jerry W Gilley, and Heather S Mcmillan. “Organizational Change: Motivation, Communication, and Leadership Effectiveness." Wiley Inter Science 21, no. 1 (2009): 75-94. https://doi.org/10.1002/piq.

Hancock, Linda, and Sonia Nuttman. "Engaging Higher Education Institutions in the Challenge of Sustainability: Sustainable Transport as a Catalyst for Action." Journal of Cleaner Production, 2014. https://doi.org/10.1016/j.jclepro.2013.07.062.

Hoy, Wayne K., and Cecil G. Miskel. Educational Administration Theory, Research, and Practice 6th Ed., International Edition. Singapore: McGraw-Hill Co, 2008. 
Ismail, Hanif, and Darsono Prawironegoro. Sistem Pengendalian Manajemen, Konsep Dan Aplikasinya. Jakarta: Mitra Wacana Media, 2009.

Istikomah. "Efektivitas Kepemimpinan Kepala Sekolah Pada SMK Negeri 4 Di Kota Jambi." IDARAH | Jurnal Pendidikan Dan Kependidikan 3, no. 2 (2019): 39-55. https://ejurnal.iainlhokseumawe.ac.id/index.php/idarah.

Kadarisman. Manajemen Pengembangan Sumber Daya Manusia. Jakarta: Raja Grafindo Persada, 2013.

Kodama, Mitsuru. "Business Innovation Through Holistic Leadership-Developing Organizational Adaptability.” Systems Research and Behavioral Science 36, no. 4 (2019): 365-94.

Krasny, Marianne E., and Wolff Michael Roth. "Environmental Education for Social-Ecological System Resilience: A Perspective from Activity Theory." Environmental Education Research 16, no. $5-6$ (2010):

545-58.

https://doi.org/10.1080/13504622.2010.505431.

Macredie, Robert D, Carl Sandom, and Ray J Paul. "Modelling for Change: An Information Systems Perspective on Change Management Models.” Brunel University, Uxbridge, Middlesex, 1991.

Mahendra, Angga Martha, Ery Tri Djatmika, and Agus Hermawan. "The Effect of Entrepreneurship Education on Entrepreneurial Intention Mediated by Motivation and Attitude among Management Students, State University of Malang, Indonesia.” International Education 2017. https://doi.org/10.5539/ies.v10n9p61.

Mangkunegara, Anwar Prabu. Perencanaan Dan Pengembangan Sumber Daya Manusia. Bandung: Refika Aditama, 2010.

McShane, Steven L., and Mary Ann Von Glinow. Organizational Behaviour : Emerging Knowledge Global Reality. New York: McGrawHill Education, 2018.

Mukhtar et. al. Pesantren Efektif, Moderl Integratif Kepemimpinan Komunikasi - Konflik Organisasi. Yogyakarta: Deepublish, 2020. Mukhtar, Risnita, and Istikomah. "The Influence of Principals' 
Leadership Style, the Organizational System and Work Motivation on School Effectiveness." International Journal of Scientific and Technology Research 8, no. 11 (2019): 91-104.

Nisjar, Kahri, and Winardi. Teori Sistem Dan Pendekatan Sistem Dalam Bidang Manajemen. Bandung: Mandar Maju, 1997.

O’Brien, Karen, Jonathan Reams, Anne Caspari, Andrew Dugmore, Maryam Faghihimani, Ioan Fazey, Heide Hackmann, et al. "You

Say You Want a Revolution? Transforming Education and Capacity Building in Response to Global Change." Environmental Science and Policy 28 (2013): 48-59. https://doi.org/10.1016/j.envsci.2012.11.011.

Rivai, Veithzal, and Sylviana Murni. Education Management. Analisis Teori Dan Praktek. Jakarta: Raja Grafindo Persada, 2009.

Robbins, Stephen P. Teori Organisasi, Struktur, Desain, \& Aplikasi, Edisi Ke-3. Edited by Jusuf Udaya. 3rd ed. Jakarta: Penerbit Arcan, 2014. Robbins, Stephen P., and T. M. Judge. Organizational Behavior. (12th Ed.). New Jersey: Pearson Education, 2010.

Saffa, Michael, and Mohamed Jabbie. "Developing Transformational Competencies for Sustainable Development." In Quality Education, edited by Walter Leal Filho, Anabela Marisa Azul, Luciana Brandli, Pinar Gökçin Özuyar, and Tony Wall, 149-58. Cham: Springer International Publishing, 2020. https://doi.org/10.1007/978-3-319-95870-5_116.

Saira Yousaf et.al. "Impact of Financial and Non Financial Rewards on Employee Motivation.” Middle-East Journal of Scientific Research 21, no. 10 (2014).

Schell, George P., and Raymond McLeod. Management Information System, 9th Edition. New Jersey: Prentice Hall, 2014.

Siagian, Sondang P. Kiat Meningkatkan Produktivitas Kerja. Jakarta: Rineka Cipta, 2009.

Silverthorne, Colin P. Organizational Psychology In Cross-Cultural Perspective. New York: New York University Press, 2005.

Siregar, Fauzan Ahmad. "Membangun Loyalitas Tenaga Pendidik." IDARAH | Jurnal Pendidikan Dan Kependidikan 1, no. 1 (2017): 11728. https://ejurnal.iainlhokseumawe.ac.id/index.php/idarah. 
Soebahar, Abd. Halim. Kebijakan Pendidikan Islam Dari Ordonansi Guru Sampai UU Sisdiknas. Depok: Raja Grafindo Persada, 2012.

Sopiah. Perilaku Organisasi. Yogyakarta: Andi Publishing, 2018.

Steiner, Meir, Richard J Katz, Giulio Baldrighi, and Bernard J Carroll.

"Motivated Behavior and The Estrous Cycle in Rats." Psychoneuroendocrinology 6, no. 1 (1981): 81-90.

Sukatin. "Budaya Organisasi STAI YASNI Kabupaten Muaro Bungo Provinsi Jambi." IDARAH | Jurnal Pendidikan Dan Kependidikan 2, no. 2 (2018): $55-73$.

https://ejurnal.iainlhokseumawe.ac.id/index.php/idarah.

Sunyoto, Danang. Sistem Informasi Manajemen (Perspektif Oragnisasi). Yogyakarta: Buku Seru, 2014.

Supardi. Sekolah Efektif, Konsep Dasar Dan Praktiknya. 2nd ed. Jakarta: Raja Grafindo Persada, 2015.

Terry, George R. Prinsip-Prinsip Manajemen. Jakarta: Bumi Aksara, 2009.

Triatna, Cepi. Perilaku Organisasi Dalam Pendidikan Dalam Pendidikan. Bandung: Remaja Rosda Karya, 2016.

Uha, Ismail Nawawi. Budaya Organisasi, Kepemimpinan Dan Kinerja. Jakarta: Kencana Prenada Media Grup, 2015.

Usman, Husaini. Manajemen, Teori, Praktik, Dan Riset Pendidikan Edisi 4. 4th ed. Jakarta: Bumi Aksara, 2013.

Wibowo. Manajemen Kinerja Edisi Ke 5. Jakarta: Raja Grafindo Persada, 2017.

Wigfield, A., and J. S. Eccles. Development of Achievement Motivation. San Diego: Academic Press, 2002.

Winardi, J. Teori Organisasi Dan Pengorganisasian. Cet ke-8. Jakarta: Raja Grafindo Persada, 2014.

Wirawan. Kepemimpinan, Teori, Psikologi, Perilaku Organisasi, Aplikasi Dan Penelitian, Contoh Aplikasi Untuk Kepemimpinan Wanita, Organisasi Bisnis, Pendidikan, Dan Militer. Jakarta: Raja Grafindo Persada, 2017. 